DANUTA GURDAK*-KRAKÓW

,....od tego bowiem jakim jest bibliotekarz zależeć będzie i biblioteka. Wraz z bibliotekarzem stoi lub upada biblioteka"1.

\title{
KSIEDZ DR HAB. JAN BEDNARCZYK - ŻYCIE I DZIAŁALNOŚĆ NA NIWIE BIBLIOTEKARSKIEJ
}

Celem niniejszego artykułu jest przybliżenie postaci ks. dra hab. Jana Bednarczyka, przedstawienie jego biografii, osiągnięć, działalności naukowej i organizacyjnej oraz ukazanie jego wkładu w dziedzinie bibliotekoznawstwa i bibliotekarstwa pragmatycznego, nie pomijając pracy ewangelizacyjnej i duszpasterskiej².

Jednocześnie, wykazanie najistotniejszych efektów jego działań - w okresie 28 lat pracy w Bibliotece Uniwersytetu Papieskiego Jana Pawła II w Krakowie, w tym 23 lat zarządzania nią - ma na celu przytoczenie budującego przykładu kapłana, który łącząc obowiązki związane z pełnionymi funkcjami, pracą naukową, duszpasterską, zachowującego niezmiennie wzorową postawę, osiągnął realizację swych marzeń - podniósł bibliotekę, w znacznej mierze o cechach i tradycji biblioteki seminaryjnej, do rangi nowoczesnej, otwartej biblioteki naukowej.

\section{Biografia naukowa}

Jan Bednarczyk urodził się 31 sierpnia 1947 roku w Toporzysku koło Jordanowa, gdzie ukończył szkołę podstawową. Egzamin dojrzałości złożył w Liceum Ogólnokształcącym w Jordanowie, w roku 1965. Jako alumn Arcybiskupiego Wyższego Seminarium Duchownego podjął studia filozoficzno-teologiczne na

* Danuta Gurdak - mgr pedagogiki kulturalno-oświatowej, kustosz dyplomowany w Bibliotece Głównej Uniwersytetu Papieskiego Jana Pawła II w Krakowie.

${ }^{1}$ Cytat zaczerpnięty z wypowiedzi Franciszka Chwalewskiego, wygłoszonej podczas uroczystości wręczenia Medalu za Zasługi dla Katolickiego Uniwersytetu Lubelskiego, która odbyła się w Bibliotece Uniwersyteckiej KUL w dniu 8 grudnia 2009 roku [on-line]. Tryb dostępu: http://www. bu.kul.pl/medal-za-zaslugi-dla-katolickiego-uniwersytetu-lubelskiego-przemowienie-franciszkachwalewskiego,art_20905.html [dostęp 21.08. 2012].

${ }^{2}$ Artykuł powstał m.in. w oparciu o życiorys ks. dra hab. Jana Bednarczyka. 
Papieskim Wydziale Teologicznym w Krakowie, które ukończył ze stopniem magistra teologii.

W 1971 r. został wyświęcony na kapłana archidiecezji krakowskiej przez kard. Karola Wojtyłę, na którego polecenie, w latach 1971-1978, pracował w charakterze wikariusza w parafiach w Sieprawiu, Inwałdzie i Krakowie. Natomiast od roku 1979 do 1984 pełnił funkcje duszpasterskie zlecone mu przez kard. Franciszka Macharskiego w parafiach: Żywiec, Zielonki, Kraków.

Ksiądz Bednarczyk, wraz z pracą duszpasterską, umiał połączyć realizację swego rozwoju naukowego. W tym bowiem okresie (1974-1976) uczęszczał na wykłady i ćwiczenia w Studium Życia Wewnętrznego przy Papieskim Wydziale Teologicznym w Krakowie i kontynuował studia na tej uczelni także w kolejnych latach. Ich owocem były prace dyplomowe - w 1979 roku Wspótczesne zakwestionowanie wiary w ujęciu Heinricha Friesa [...], a w 1981 roku Współczesna problematyka wiary i nauki w ujęciu Jeana Ladriere'a - oraz uzyskanie w tymże 1981 roku stopnia licencjata teologii.

Nowy i ważny etap w życiu ks. Jana Bednarczyka rozpoczął się w roku 1984, gdy decyzją kard. Franciszka Macharskiego został zwolniony z obowiązków wikariusza parafii pw. Wszystkich Świętych w Krakowie i skierowany do pracy w Papieskiej Akademii Teologicznej. Podjął tam obowiązki bibliotekarza, i aby wypełniać je jak najlepiej, rozpoczął studia w zakresie bibliotekoznawstwa i informacji naukowej w Instytucie Filologii Polskiej Uniwersytetu Jagiellońskiego. Ukończył je w 1988 roku, uzyskując tytuł magistra bibliotekoznawstwa i informacji naukowej na podstawie pracy Bieżace czasopisma zagraniczne w wybranych bibliotekach kościelnych Krakowa w latach 1981-1986, napisanej pod kierunkiem prof. dr hab. Marii Kocójowej. Od tej pory trwa jego związek i współpraca z Instytutem Informacji Naukowej i Bibliotekoznawstwa Uniwersytetu Jagiellońskiego poprzez zaangażowanie w pracę naukowo-dydaktyczną.

Równocześnie kontynuował studia na Wydziale Filozoficznym Papieskiej Akademii Teologicznej, które w 1990 roku zwieńczył rozprawą doktorską, pisaną pod kierunkiem ks. prof. dra hab. Mariana Jaworskiego (obecnie kardynała) pt. Wiara religijna w ujęciu Władysława Witwickiego. Habilitację z zakresu teologii zdobył w 2008 roku na Wydziale Teologicznym Papieskiej Akademii Teologicznej w Krakowie na podstawie dorobku naukowego oraz dysertacji Ewangelizacyjna rola bibliotek parafialnych $w$ Archidiecezji Krakowskiej.

Na stanowisko dyrektora Biblioteki Papieskiej Akademii Teologicznej w Krakowie ks. J. Bednarczyk został mianowany w 1989 roku. Nie zaniedbując swoich obowiązków wynikających z pełnionych funkcji, pracy naukowej i duszpasterskiej, nieustannie podnosił swoje kwalifikacje, m.in. uczestnicząc w zagranicznych kursach językowych (1983-1989), natomiast w 1991 roku przebywał na stypendium w Bibliotece Ruhr-Universität w Bochum. W latach 1994-2001 był przewodniczącym polskiej Federacji Bibliotek Kościelnych - FIDES. Stopień kustosza dyplomowanego uzyskał $\mathrm{w}$ wyniku postępowania kwalifikacyjnego przed Komisją Egzaminacyjną powołaną w trybie przepisów rozporządzenia Ministra Nauki i Szkolnictwa Wyższego w roku 2011.

Jako Dyrektor Biblioteki był inicjatorem budowy nowego gmachu bibliotecz- 
nego i aktywnie uczestniczył $\mathrm{w}$ pracach związanych $\mathrm{z}$ realizacją tego projektu. Powierzone stanowisko Dyrektora Biblioteki Uniwersytetu Papieskiego Jana Pawła II w Krakowie piastował do końca sierpnia 2012 roku.

Jego wysiłek i praca naukowo-dydaktyczna zostały docenione. W 2007 roku, postanowieniem Prezydenta Rzeczpospolitej Polskiej Lecha Kaczyńskiego, na wniosek Ministra Nauki i Szkolnictwa Wyższego - za wzorowe, wyjątkowo sumienne wykonywanie obowiązków wynikających z pracy zawodowej - ks. Jan Bednarczyk został odznaczony Złotym Krzyżem Zasługi.

Należy również podkreślić wielkie zasługi i znaczący wkład ks. Jana Bednarczyka w tworzeniu nowej parafii w jego rodzinnej miejscowości. W każdym okresie, także w czasie swej krakowskiej działalności i zarządzania Biblioteką, ks. Jan Bednarczyk nie zapominał o osobistej formacji duchowej. Posługą duszpasterską obejmował również środowisko bibliotekarskie, alumnów Wyższego Seminarium Duchownego Archidiecezji Krakowskiej, będąc ich spowiednikiem w latach 1993-2003. Prowadził rekolekcje w 20 parafiach, w 71 parafiach trzech okolicznych diecezji (1991-1997) wygłaszał kazania i zapoznawał wiernych z misją Papieskiej Akademii Teologicznej w Krakowie, a otrzymane ofiary przeznaczone były na jej działalność. Głosił również homilie i kazania z okazji różnych świąti uroczystości religijnych, pełnił posługę w konfesjonale. Za swą służbę wobec Ludu Bożego poprzez nauczanie, uświęcanie i troskę duszpasterską, a także wieloletnią pracę w bibliotece został obdarzony przez papieża Benedykta XVI w roku 2012 godnością Kapelana Ojca Świętego.

Chcąc powrócić do istoty kapłaństwa, w lipcu 2012 roku, po 28 latach pracy w Bibliotece, ustępując z pełnionej przez 23 lata funkcji Dyrektora Biblioteki Uniwersytetu Papieskiego Jana Pawła II, ks. dr hab. Jan Bednarczyk oddał się pracy duszpasterskiej i objął jako proboszcz parafię pod wezwaniem Matki Bożej Wniebowziętej w Filipowicach koło Krakowa.

\section{Działalność naukowa}

Ksiądz Jan Bednarczyk, ukończywszy trzy fakultety, zdobywając stopnie dra hab. teologii, dra filozofii, mgra bibliotekoznawstwa i informacji naukowej oraz tytuł i kwalifikacje kustosza dyplomowanego, rozwinął szerokie spektrum zainteresowań i działań naukowych.

Jest członkiem wielu komisji, towarzystw naukowych, rad dyrektorów i fundacji. W okresie zarządzania Biblioteką Uniwersytetu Papieskiego Jana Pawła II brał udział w konferencjach naukowych, krajowych i zagranicznych, sympozjach i spotkaniach w kraju i zagranicą (m. in. w Krakowie, Warszawie, Lublinie, Wrocławiu, Olsztynie, Białymstoku, Opolu, Rzymie, Strasburgu, Paryżu, Lille, Pannonhalma, Kolonii, Montpellier), podczas których wygłaszał referaty, komunikaty, brał udział w dyskusjach, a także przewodniczył obradom.

Ks. dr hab. Jan Bednarczyk od 1994 r. prowadzi zajęcia dydaktyczne ze studentami Instytutu Informacji Naukowej i Bibliotekoznawstwa Uniwersytetu Jagiellońskiego. Od roku 2008 uczestniczy w posiedzeniach Rady Naukowej tegoż Instytutu, od 2009 prowadzi tam także seminarium magisterskie, a od 2010 jest członkiem Komisji Dydaktycznej. Od roku 2009 ma zajęcia w Podyplomowym 
Studium z Archiwistyki i Bibliotekoznawstwa Uniwersytetu Papieskiego Jana Pawła II w Krakowie.

Niezmiennie mobilizował bibliotekarzy Biblioteki Uniwersytetu Papieskiego Jana Pawła II do aktywności i pracy twórczej w zakresie bibliotekarstwa naukowego - wiele z nich podejmowało dydaktykę, zaś kilka osób skierowanych przez swego Dyrektora, ks. dra hab. Bednarczyka do postępowania kwalifikacyjnego uzyskało kwalifikacje dyplomowanego bibliotekarza, zdając egzamin przed Komisją Egzaminacyjną, powołaną przez Ministra Nauki i Szkolnictwa Wyższego.

Opublikował ponad 100 artykułów naukowych i popularno-naukowych z zakresu zagadnień bibliotekarskich, teologicznych, filozoficznych, w wydawnictwach zwartych i ciągłych. Jego działalność naukowa obejmuje również udział w redagowaniu czasopism. $\mathrm{Z}$ jego inicjatywy powołano do życia półrocznik $F I$ DES - Biuletyn Bibliotek Kościelnych, jako organ Federacji Bibliotek Kościelnych FIDES. W latach 1995-2011 ks. dr hab. Jan Bednarczyk był redaktorem naczelnym tegoż biuletynu, który od 2009 roku stał się czasopismem recenzowanym. Od 1992 roku pełni funkcję jednego z sekretarzy zespołu redakcyjnego podstawowego periodyku Papieskiej Akademii Teologicznej - od 2009 roku Uniwersytetu Papieskiego Jana Pawła II - Analecta Cracoviensia. Jest także redaktorem książki Historia vita memoriae (Kraków, 2009; 2010).

Twórczość i działalność naukowa ks. dr hab. Jana Bednarczyka obejmuje dwa nurty, jeden teologiczno-filozoficzny, dotyczy zagadnień metafizyki i filozofii religii oraz teologii fundamentalnej i pastoralnej, drugi związany jest z zainteresowaniami w dziedzinie bibliotekoznawstwa. Taki zakres zainteresowań związany jest z jego drogą życiową - kapłana i duszpasterza w parafiach oraz pracownika Uniwersytetu Papieskiego Jana Pawła II w Krakowie.

Kroczy przez życie ze świadomością konieczności doskonalenia swojej wiedzy, ale i potrzeby twórczego wkładu w rozwój dziedzin związanych z jego powołaniem i wykonywaną pracą. Swą przynależnością do świata duchowości i nauki, jednocześnie przez działalność bibliotekarską i bibliofilską, aktywnie przyczynia się do pomnażania i zachowania spuścizny kulturowej budowanej na wartościach chrześcijańskich - a mówiąc słowami bł. Jana Pawła II - do tworzenia „patrymonium kultury i nauki"3.

Ważny obszar dotychczasowych prac badawczych ks. Bednarczyka koncentrował się na określeniu zadań i funkcji pracy ewangelizacyjnej, szczególnie w parafiach, które w przeszłości, obecnie i w przyszłości były, są i mogłyby być optymalnie wspierane przez dobrą i nowoczesną bibliotekę kościelną.

Dotychczasowa jego działalność w zakresie bibliotekoznawstwa była ukierunkowana na rozwój i unowocześnianie sposobów i metod funkcjonowania bibliotek, szczególnie kościelnych, wprowadzenie nowych form ich współpracy

${ }^{3}$ Zob. Biblioteka Uniwersytecka w Warszawie - Wizyta Papieża Jana Pawła II, 11 czerwca 1999 r. [Tekst przemówienia on-line]. [Dostęp 21.08.2012]. Tryb dostępu: http://www.buw.uw.edu. $\mathrm{pl} /$ index.php?option $=$ com_cintent\&task $=$ view\&id=305\&Itemd $=76$ oraz fragment tekstu przemówienia przytoczony w artykule: J. Bednarczyk, Działalność Federacji Bibliotek Kościelnych Fides w okresie 26 czerwca1998 - 29 listopada 1999 r., „FIDES - Biuletyn Bibliotek Kościelnych”, 2 (1999) s. 59. 
regionalnej, krajowej i międzynarodowej w ramach sieci bibliotecznych o mniej lub bardziej sformalizowanej strukturze organizacyjnej i funkcjonalnej, a także na doskonalenie obsługi czytelników w oparciu o komputeryzację bibliotek i wprowadzanie nowoczesnych technologii.

Obydwa nurty zainteresowań naukowych rozwijanych przez ks. dra hab. Bednarczyka i rozważań teoretycznych z powodzeniem przełożyły się na pole działań praktycznych.

\section{Działalność organizacyjna}

Ksiądz Jan Bednarczyk działał aktywnie na rzecz współpracy i integracji środowiska bibliotekarskiego, poprzez rozwijanie różnorodnych przedsięwzięć i kontaktów z innymi bibliotekami, ośrodkami naukowymi i badawczymi, tak w skali lokalnej, jak i ogólnokrajowej.

Działania i pełnione funkcje ks. dr hab. Jana Bednarczyka są zatem na przestrzeni lat bardzo liczne i różnorodne. W ramach Uczelni, od 1991 roku był członkiem Senackiej Komisji Bibliotecznej, i od roku 1995 przewodniczącym Senackiej Komisji ds. Badań Naukowych, w okresie 2004-2009 był jej współprzewodniczącym. W latach 1994-1997 uczestniczył jako delegat Papieskiej Akademii Teologicznej w ogólnopolskich konferencjach Komitetu Badań Naukowych. W 1994 jego Magnificencja Rektor PAT uczynił księdza Bednarczyka odpowiedzialnym za korzystanie przez pracowników Uczelni z sieci Internet za pośrednictwem Akademickiego Centrum Komputerowego (ACK) Cyfronet.

W 1989 roku ks. dr hab. Jan Bednarczyk został przyjęty do Kolegium Dyrektorów Bibliotek Naukowych Krakowa. Jest również członkiem: od roku1985 Zarządu Polskiego Towarzystwa Teologicznego, od 2005 roku także „Komisji Programowej" wydawnictwa tegoż Towarzystwa, a od 1990 r. Zarządu Fundacji św. Królowej Jadwigi dla Papieskiej Akademii Teologicznej, zaś od 2010 r. Rady tej Fundacji; w latach 1990-2011 Polskiego Towarzystwa Bibliologicznego - oddział w Krakowie; od 1994 roku Krakowskiej Rady Użytkowników Komputerów Dużej Mocy Obliczeniowej (KDMO) i miejskiej Sieci Komputerowej (MAN) przy ACK Cyfronet, AGH i Rady Dyrektorów Porozumienia o Współpracy Bibliotek Wdrażających i Użytkujących VTLS/Virtua.

Będac od roku 1997 członkiem Konferencji Dyrektorów Bibliotek Akademickich Szkół Polskich, zaprosił Dyrektorów zrzeszonych w Konferencji na doroczne obrady w dniach 17-18 września 2012, do nowego gmachu Biblioteki Uniwersytetu Ppieskiego Jana Pawła II.

Jest też wieloletnim (od roku 1994) członkiem Rady Dyrektorów Krakowskiego Zespołu Bibliotecznego, od 1998 r. Komitetu Sterującego KZB, od 2002 r. Rady Fundacji Powrót, od 2004 r. Rady Archiwum i Biblioteki Kapituły Metropolitalnej w Krakowie, a także Rady Fundacji Polska Biblioteka Internetowa.

Od roku 1999 pełnił funkcję przewodniczącego Grupy Doradczej ds. Budowy Biblioteki PAT oraz stał na czele Zespołu Pracowników powołanego w związku z przystąpieniem do projektowania i budowy nowego gmachu bibliotecznego ${ }^{4}$.

${ }^{4}$ J. Bednarczyk, Budujemy biblioteke, ,Vita Academica”, 1/2 (2001) s. 11. 
Jako Dyrektor Biblioteki Papieskiej Akademii Teologicznej, od 1991 roku współtworzył polską Federację Bibliotek Kościelnych FIDES, będąc jej przewodniczącym w latach 1994-20015. W tym okresie organizował Walne Zgromadzenia Federacji, posiedzenia jej zarządu, wydawał wspomniany już FIDES - Biuletyn Bibliotek Kościelnych, organizował kursy szkoleniowe różnych stopni z zakresu komputeryzacji bibliotek kościelnych i korzystania z Internetu, a także spotkania regionalne. Wówczas również został zatwierdzony Statut Federacji FIDES przez Konferencję Episkopatu Polski i uzyskała ona osobowość prawną w 1995 roku. Jako przewodniczący Federacji ks. dr hab. Jan Bednarczyk zabiegał o rozszerzenie współpracy międzynarodowej polskich bibliotek kościelnych ${ }^{6}$. We wrześniu 1995 roku, dzięki jego staraniom, Federacja FIDES została zwyczajnym członkiem Conseil International des Associations de Bibliothčques de Teologie (CIABT), (od 1998 roku pod nazwą: Bibliothèques Européenes de Théologie BETH). Ks. dr hab. Bednarczyk brał udział w posiedzeniach Assemblée Générale CIABT, w latach 1986-1994 jako przedstawiciel Biblioteki Papieskiej Akademii Teologicznej, a w latach 1995-1999 jako przedstawiciel Federacji FIDES. Z okazji 600-lecia Wydziału Teologicznego w Krakowie, z ramienia Papieskiej Akademii Teologicznej i Federacji FIDES organizował w dniach 12-18.09.1998 roku Assemblée Générale tej Międzynarodowej Rady, w którym uczestniczyli przedstawiciele krajowych stowarzyszeń bibliotek teologicznych z Europy i USA. Po zakończeniu pełnienia funkcji przewodniczącego tej Federacji ks. Jan Bednarczyk nadal pozostaje jej członkiem.

Między rokiem 1989 a 1991 ks. dr hab. Jan Bednarczyk zorganizował 4 spotkania dla bibliotekarzy krakowskich, dotyczące zagadnień komputeryzacji bibliotek, w których uczestniczyło ponad sto osób. Od roku 1992 - wespół z prof. Marią Kocójową - czynnie współorganizował ze środowiskiem naukowym Instytutu Informacji Naukowej i Bibliotekoznawstwa Uniwersytetu Jagiellońskiego (nie pomijając studentów), Polskim Towarzystwem Bibliologicznym - Oddział w Krakowie, coroczne spotkania opłatkowe dla pracowników książki, a zwłaszcza bibliotekarzy, archiwistów i księgarzy oraz nauczycieli akademickich i studentów bibliotekoznawstwa i informacji naukowej w Krakowie. Jako człowiek zawsze głęboko angażujący się w sprawy kultury, był także inicjatorem i organizatorem kilku wieczorów poetyckich pracowników Biblioteki Uniwersytetu Papieskiego Jana Pawła II.

W latach 1995-1997 ks. Jan Bednarczyk zabiegał o doprowadzenie połączeń światłowodowych do budynków Uczelni. W okresie sprawowania funkcji Dyrektora Biblioteki Uniwersytetu Papieskiego Jana Pawła II w Krakowie zostały uno-

${ }^{5}$ Zob. J. Bednarczyk, Powołanie do życia Federacji Bibliotek Kościelnych - FIDES, „Archiwa Biblioteki i Muzea Kościelne”, 65 (1996) s. 69-78; tenże, Federacja Bibliotek Kościelnych FIDES, w: Czy stowarzyszenia sa dzisiaj potrzebne: tradycje i teraźniejszość na przykładzie stowarzyszeń działajacych na terenie poludniowej Polski: materiały z sympozjum, Kraków 2-3 grudnia 1994 roku, red. R. Majkowska, Kraków 2000, s.185-192.

${ }^{6}$ D. Rebech, Biblioteka Papieskiej Akademii Teologicznej w Krakowie w działalności Federacji Bibliotek Kościelnych FIDES, „FIDES - Biuletyn Bibliotek Kościelnych”, 20/21 (2005) nr1/2, s. 50-73. 
wocześnione sposoby i metody jej działalności, m.in. zapewniono światłowodowy i bezprzewodowy dostęp do Internetu dla pracowników i czytelników, wprowadzono w szerokim zakresie komputeryzację (ok. 130 komputerów), rozwinięto aktywny udział w komputerowych sieciach bibliotecznych Krakowskiego Zespołu Bibliotecznego (KZB), Narodowego Uniwersalnego Katalogu (NUKAT), Federacji Bibliotek Kościelnych FIDES oraz w bibliotekach wirtualnych: Polskiej Bibliotece Internetowej (PBI) i Małopolskiej Bibliotece Cyfrowej (MBC).

W tym też czasie znacznie zwiększyła się liczba wysoko wykwalifikowanych pracowników Biblioteki Uniwersytetu Papieskiego Jana Pawła II, księgozbiór powiększył się z ok. 100 tys. woluminów do ponad 600 tys., wzrosła liczba czytelników z ok. 2 tys. do prawie 9,5 tys. ${ }^{7}$

Ksiądz Dyrektor przez wiele lat zabiegał o stworzenie lepszych warunków lokalowych dla uczelnianej Biblioteki. Angażował się w prace koncepcyjne i projektowe nowego gmachu Biblioteki, jako pierwszego budynku przyszłego Kampusu UPJPII przy ul. Bobrzyńskiego $10 \mathrm{w}$ Krakowie. Następnie bardzo aktywnie uczestniczył w różnych pracach związanych z jej budową. Przyczyniał się do pozyskiwania przez Uczelnię dodatkowych funduszy na wspomaganie działalności badawczej i dofinansowania ze środków Unii Europejskiej w ramach Małopolskiego Regionalnego Projektu Operacyjnego 2007-2013 (MRPO) Budowa Biblioteki Papieskiej Akademii Teologicznej w Krakowie - dokończenie ${ }^{8}$. Wybudowany i wyposażony nowoczesny gmach biblioteczny, o powierzchni użytkowej prawie 9 tys. $\mathrm{m}^{2}$ został udostępniony czytelnikom od stycznia 2011 roku. Uczelnia wzbogaciła się więc o nowy warsztat pracy, spełniający wymogi obecnych czasów.

\section{Zakończenie}

W strukturze Uniwersytetu Papieskiego Jana Pawła II w Krakowie i poza nią, ks. dr hab. Jan Bednarczyk podejmował i realizował bardzo liczne zadania, mając na względzie budowanie Biblioteki - zarówno jako instytucji, zespołu ludzi, jak i w dosłownym znaczeniu - bogatej w zbiory, przy zastosowaniu technologii informacyjno-informatycznych i infrastruktury technicznej, umożliwiającej szybki, łatwy i wygodny dostęp do poszukiwanych materiałów. Dążenia te miały na celu tworzenie silnego i nowoczesnego zaplecza umożliwiającego i wspierającego uprawianie dyscyplin naukowych zgodnie z profilem rozwijającej się Uczelni.

Aspiracje i dążenia te zostały zrealizowane z sukcesem. Powstała piękna, przyjazna i nowoczesna biblioteka, oferująca zbiory w wolnym dostępie. Mieści się w budynku, który jako realizacja projektu biura Ingarden \& Ewý, uzyskał nominację do Nagrody Roku Stowarzyszenia Architektów Polskich (SARP) dla najlepszej realizacji powstałej w 2011 roku. Wielofunkcyjna przestrzeń, umożliwia-

${ }^{7}$ A. Nowicka, Zarys dziejów Biblioteki Papieskiej Akademii Teologicznej w Krakowie, „,FIDES - Biuletyn Bibliotek Kościelnych”, 20/21 (2005) nr 1/2, s. 37-49.

${ }^{8}$ W. Szczęch, Pozyskiwanie środków na budowe, wyposażenie i sprzęt w Bibliotece Uniwersytetu Papieskiego Jana Pawła II w Krakowie, „FIDES - Biuletyn Bibliotek Kościelnych”, 30/31 (2010) nr 1/2, s. 5-14.

${ }^{9}$ K. Ingarden, Falujacy horyzont: Biblioteka Uniwersytetu Papieskiego Jana Pawła II w Krakowie, „Świat Architektury”, 16 (2011) nr 9, s. 66-71. 
jąca działanie zespołu bibliotecznego w warunkach nowoczesnej organizacji struktury bibliotecznej i postępu technologicznego, może stanowić sama w sobie inspirację i bodziec do rozwoju pracowników tworzących tę strukturę. Można więc mówić o wypracowanym postępie, gdyż - dzięki konsekwentnemu realizowaniu wyznaczonego przez swego Dyrektora kierunku - Biblioteka Uniwersytetu Papieskiego Jana Pawła II zmienia się wraz ze zmieniającym się społeczeństwem i stara się nadążać za potrzebami coraz bardziej wymagających użytkowników.

Trzeba nadmienić, że ks. Dyrektor Biblioteki umiał znajdować odpowiednich współpracowników i stworzyć oddany sobie Zespół, by wspólnym wysiłkiem realizować wytyczane koncepcje i plany. Swą codzienną postawą stanowił wzór skromności, wytrwałej pracy oraz mądrości i odwagi w pokonywaniu przeszkód, stojących nierzadko na drodze w realizacji zamierzonych celów ${ }^{10}$.W Bibliotece tej pracują bibliotekarze o wysokich kwalifikacjach, najczęściej zdobytych właśnie w tym miejscu i pod jego auspicjami. Swoim następcom ks. J. Bednarczyk powierza zatem sprawnie funkcjonującą i nowoczesną Instytucję.

Ksiądz dr hab. Jan Bednarczyk, przechodząc od czynnej działalności związanej ze światem bibliotek, pozostawiając piękne dzieło wieńczące jego wieloletnią pracę i wybierając ponownie pracę duszpasterską, którą jak klamrą z początków kapłaństwa spina swoje nieustannie aktywne życie, wskazuje na budowanie życia duchowego i umacnianie wiary, jako najważniejsze zadanie człowieka wierzącego.

\section{Wykaz wybranych publikacji ks. dr hab. Jana Bednarczyka}

Władystawa Witwickiego koncepcja relacji między nauka a wiara, ,Analecta Cracoviensia", 24 (1992) s. 3-23.

Biblioteki kościelne w Polsce, w: Materiały XV Sesji Statej Konferencji Archiwów, Bibliotek i Muzeów Polskich na Zachodzie 23-26 września 1993, red. M. Jagosz, Rzym 1994, s. 79-89.

Ku lepszej organizacji pracy w bibliotekach kościelnych - Federacja FIDES, „Fides - Biuletyn Bibliotek Kościelnych", 1 (1995) s. 21-32.

Fédération des Bibliothèques Ecclésiastiques de Pologne (FIDES), w: Conseil International des Associations de Bibliothèques de Théologie, Leuven 1996, s. $115-121$.

Niezwykty jubileusz, „Źródło”, 253 (1996) nr 44, s. 12-13.

Piórem w postudze Ewangelii: 25 lat myśli twórczej ks. Kazimierza Bukowskiego: szkic biograficzny, oprac. J. Bednarczyk, J. Majda, Kraków 1997, ss. 128.

Bibliografia publikacji ks. Kazimierza Bukowskiego (1046 poz.), w: Piórem w postudze Ewangelii: 25 lat myśli twórczej ks. Kazimierza Bukowskiego: szkic biograficzny, oprac. J. Bednarczyk, J. Majda, Kraków 1997, s. 45-102.

Rec.: S. Piech, Dzieje Wydziału Teologicznego Uniwersytetu Jagiellońskiego w latach 1880-1939, „Przegląd Piśmiennictwa Teologicznego”, 3 (1997) nr 5, s. 93 94.

${ }^{10}$ Zob. także: D. Gurdak. Dyrektor i Budowniczy Biblioteki Uniwersytetu Papieskiego Jana Pawła II w Krakowie, „Vita Academica”, 69 (2012) nr 4, s. 18-19. 
Perspektywy zatrudnienia absolwentów bibliotekoznawstwa i informacji naukowej w bibliotekach kościelnych, w: Rynek pracy a studia bibliotekoznawstwa i informacji naukowej w Polsce, red. M. Kocójowa, Kraków 1997, s. 69-70.

Biblioteka Papieskiej Akademii Teologicznej w Krakowie: zarys działalności, „Analecta Cracoviensia”, 30/31 (1998/1999) s. 425-433.

Laudacja ku czci Księdza Prof. dra hab. Tadeusza Wojciechowskiego z okazji przyznania Mu medalu wdzięczności upamiętniającego całokształt pracy dla Polskiego Towarzystwa Teologicznego w Krakowie, „Logos i Ethos”, 7 (1999) nr 1, s. 123-127.

Podstawowe pytania człowieka myślacego [rec.: R. Rożdżeński, Pytanie o sens naszej egzystencji, Kraków 1997, 128 s.], „Logos i Ethos”, 7 (1999) nr 1, s. $153-156$.

Rec.: R. Rożdżeński, Question sur le sens de notre existence, „Revue Philosophique de Louvain", 97 (1999) nº 1, s. 171-174.

Walne Zgromadzenie Międzynarodowej Rady Stowarzyszeń Bibliotek Teologicznych, Kraków 12-18 września 1998 r., „FIDES - Biuletyn Bibliotek Kościelnych", 2 (1999) s. 7-8.

General Assembly of the International Council of the Association of Theological Libraries, Kraków 12-18 September 1998, „FIDES - Biuletyn Bibliotek Kościelnych", 2 (1999) s. 9-10.

Wspótpraca bibliotek kościelnych w ramach Federacji Bibliotek Kościelnych FIDES oraz Międzynarodowej Rady Stowarzyszeń Bibliotek Teologicznych, w: Biblioteka i informacja w komunikowaniu: jubileusz 25-lecia studiów Bibliotekoznawstwa i Informacji Naukowej w Uniwersytecie Jagiellońskim, red. M. Kocójowa, Kraków 2000, s. 107-115.

Krakowskie starania o uznanie Świętej Jadwigi Królowej Patronką Europy, w: Europejskie znaczenie Świętej Jadwigi Królowej: dokumentacja w zbiorach polskich $i$ włoskich, red. M. Kocójowa, Kraków 2000, s. 39-44.

Rzeczywistość w swych aspektach zmystowo spostrzeganych $i$ niespostrzeganych [rec.: R. Rożdżeński, Spostrzegalne i niespostrzegalne, Kraków 1999, 322 s.], „Logos i Ethos”, 9 (2000) nr 2, s. 188-190.

Człowiek, który umiłowat Chrystusa i Jego Kościót: (wspomnienie), w: Diligis Me? Pasce: ksiega jubileuszowa dedykowana Biskupowi Sandomierskiemu Wacławowi Józefowi Świerzawskiemu na pięćdziesięciolecie święceń kapłańskich 1949-1999. T. 2, Sandomierz, 2000, s. 710-711.

Teofil Dlugosz (1887-1971), w: Złota Księga Papieskiej Akademii Teologicznej, red. S. Piech, Kraków 2000, s. 469-474.

Pótwiecze działalności dydaktyczno-naukowej Profesora Tytusa Górskiego (Curriculum vitae), „FIDES - Biuletyn Bibliotek Kościelnych”, 1/2 (2000) s. 4549.

Działalność Biblioteki Papieskiej Akademii Teologicznej w Krakowie, „Notes Biblioteczny", 195 (2001) nr 1, s. 3-14.

Budowa Biblioteki Papieskiej Akademii Teologicznej w Krakowie, „Biuletyn Duszpasterski", t. $9 \mathrm{nr} 82$ (2001)=3, s. 92-95. 
Wychowanek Uniwersytetu Jagiellońskiego pierwszym łacińskim kardynałem na Ukrainie, „Alma Mater”, 29 (2001) s. 21-22.

Biblioteka dziękuje ś.p. Ks. prof. Józefowi Tischnerowi, „Vita Academica”, 5 (2001), s. 14.

Sanktuarium nauki i madrości: z ks. Janem Bednarczykiem, dyrektorem Biblioteki PAT, rozmawia Magdalena Suchy, „Vita Academica”, 6 (2001) s. 14.

Spetnione marzenia! Ojciec Święty przybyt i pobłogosławił uczelniany Kampus, „Vita Academica”, 5 (2002) s. 3-5, 7.

Dobroczyńca, w: Z radościa głoszę Ewangelię: 85 lat życia Księdza Biskupa Albina Małysiaka: księga pamiątkowa, [oprac. i red. K.R. Prokop], Kraków 2003, s. 141-142.

W progach teologicznej ksiażnicy, w: Archidiecezja Krakowska na przełomie tysiacleci, [red. S. Koperek et al.], Kraków 2004, s. 511-514.

Integracja krakowskiego środowiska bibliotekarzy = [Integration of a local librarian circle in Kraków], w: Przestrzeń informacji i komunikacji społecznej, red. M. Kocójowa, Kraków 2004, s. 183-187.

Tworzenie Polskiej Biblioteki Internetowej, w: Profesjonalna informacja w Internecie, red. nauk. M. Kocójowa, Kraków 2005, s. 80-83.

Odważna droga głębokiej wiary, niezwyktej mąrości i ofiarnej mitości Bożej, w: Scire Deum: ksiegga pamiatkowa wydana z okazji 25-lecia Papieskiej Akademii Teologicznej w Krakowie dedykowana pierwszemu jej rektorowi Jego Eminencji Kardynałowi Marianowi Jaworskiemu, red. S. Koperek i in., Kraków 2006, s. 9-20.

Wykaz publikacji ks. Kardynała Mariana Jaworskiego [294 poz.], w: Scire Deum: księga pamiątkowa wydana z okazji 25-lecia Papieskiej Akademii Teologicznej w Krakowie dedykowana pierwszemu jej rektorowi Jego Eminencji Kardynałowi Marianowi Jaworskiemu, red. S. Koperek i in., Kraków 2006, s. 2946.

Zasoby bibliotek kościelnych w tworzeniu i zachowywaniu kultury, „Archiwa Biblioteki i Muzea Kościelne", 86 (2006) s. 55-63.

Komputeryzacja Biblioteki Papieskiej Akademii Teologicznej w Krakowie, [współaut. W. Szczęch], w: Między przeszłościa, a przyszłościa, red. M. Próchnicka, A. Korycińska-Huras, Kraków 2007, s. 143-151.

Ewangelizacyjna rola bibliotek parafialnych w Archidiecezji Krakowskiej, Kraków 2007, ss. 566.

Mocno ufamy, „FIDES - Biuletyn Bibliotek Kościelnych”, 1/2 (2007) s. 215218.

Biblioteki kościelne w stużbie ewangelizacji, „Archiwa Biblioteki i Muzea Kościelne", 91 (2009) s. 5-13.

Śladami Chrystusa idacego przez wieki, w: Historia vita memoriae. Prace dedykowane ks. prof. S. L. Piechowi, pod red. J. Bednarczyka, Kraków 2009 ; 2010, s. 15-25.

Kazanie wygłoszone na pogrzebie ś.p. Danuty Gradowskiej, Cmentarz Rakowicki, Kraków 13 grudnia 2010 r., „FIDES - Biuletyn Bibliotek Kościelnych”, 30/31 (2010) nrl/2, s. 212-214. 
Stowo wstępne, w: Ksiadz Profesor Adam Kubiś, Curriculum vitae, oprac. J. Morawa, S. Postawa, Kraków 2012, s. 7-8.

Dokument Papieskiej Komisji do spraw Dóbr Kulturowych Kościoła z 1994 r., a funkcja pastoralna bibliotek kościelnych w Polsce, w: Virtuti et ingenio. Ksiega pamiatkowa dedykowana profesorowi Julianowi Dybcowi, pod red. Andrzeja K. Banacha, Kraków 2013, s. 57-69.

\title{
THE PERSON OF REV. DOCTOR HABILITATUS JAN BEDNARCZYK - THE LIFE AND ACTIVITY IN THE REALM OF THE LIBRARY'S WORLD
}

\begin{abstract}
Summary
The goal of this article is to bring near the person of rev. dr. Jan Bednarczyk, the managing director of the Library of the Pontifical University of John Paul II in Cracow in the years 1989-2012 (at the Library since 1984), to present his biography, his achievements, sciences and organizational activities, and to show his contribution to science and pragmatism connected with the libraries. $\mathrm{He}$ was the originator of construction the new library building for the increasing collection and staff as well. The rev. Jan Bednarczyk was putting a lot of effort into the execution of building the new library for years and it was finished with success. He conducted the sciences activity in the field of theology and philosophy and didactic activity connected with the librarianship. The rev. Bednarczyk took up teaching both at the UPJPII and the Jagiellonian Univeristy too. He entrusted his successors with the task of develope and looking after the modern and efficiently working library and at the present he is coming back to do the work of ministry of the Catholic Church, the same as at the beginning of his priest's life.
\end{abstract}

